\title{
管フランジ締結体の密封性能に及ぼす曲げモーメントの影響評価*
}

\author{
鳥居広康 ${ }^{* 1}$ ，高木愛夫 ${ }^{* 1}$ ， 大宮祐也 ${ }^{* 2}$ ，沢 俊行 ${ }^{* 3}$
}

\section{Effect of External Bending Moment on the Sealing Performance of Pipe Flange Connection}

\author{
Hiroyasu TORII ${ }^{* 1}$, Yoshio TAKAGI, Yuya OMIYA and Toshiyuki SAWA \\ $*^{1}$ R\&D Center, Tokyo Electric Power Company \\ 4-1, Egasaki, Tsurumi-ku, Yokohama, 230-8510, Japan
}

Since an external bending moment affected the sealing performance of pipe flange connection, it was important to investigate this effect. This paper analyzed the contact gasket stress distribution of pipe flange connections and evaluated the effect of external bending moment on the sealing performance from the viewpoint of changes in contact gasket stress. The study included the FE analyses and the experimental leakage tests. The FE analyses revealed the large decrease of contact gasket stress at tension side and small increase at compression side. The difference in change in contact gasket stress was caused by the non-linear hysterics characteristics of stress-displacement curve of gasket. The FE analyses also revealed that the loading order, internal pressure and external bending moment, also affected the sealing performance due to the non-linear deformation characteristic of the gasket. The experimental leakage tests using helium (He) gas were analyzed by the finite element method and discussed. This paper also evaluated the stress distribution in the pipe flange under external bending moment. The results suggested that the hub stress dominated the flange structure and the most important factor in designing the flange.

Key Words : Pipe Flange Connection, Sealing Performance, Gasket, Bending Moment

\section{1. 緒言}

管フランジ締結体は発電プラント，化学プラント等の機械構造物に多用されている.これら締結体が，内圧に 加えて地震などの外荷重や配管接合における変位などの曲げモーメントの作用を受けた場合，ガスケット接触面 の密封性能に影響を及ぼす場合がある。これまでの研究により，管フランジの密封性能は接触ガスケット応力に 大きく依存し, 曲げモーメントは配管系に与えられる内圧と同様に接触ガスケット応力分布を変化させる要因で あることが判明している(1)-(4). しかしながら，実機の使用条件を模擬した荷重負荷順序の影響については，ほと んど研究がなされていない. また，管フランジ締結体の設計に際して，各部位の強度評価は重要な要素であり， 曲げモーメントが作用した場合の密封性能変化やフランジ強度を把握することは，予期せぬ漏えいを防止し，よ り合理的なフランジ設計に資する重要な技術である。本研究では，曲げモーメントが密封性能ならびにフランジ 締結体の材料強度に及ぼす影響を解析的手法ならびに実験的手法により評価，考察した。

\section{2. 試験方法}

\section{$2 \cdot 1$ 漏えい試験}

漏えい試験は図 1 に示す 3 インチフランジガスケット締結体に曲げモーメントを負荷することにより実施 した．試験ガスケットには膨張黒鉛渦巻きガスケットを使用し，目標接触ガスケット応力（50，80，100MPa） となるように歪みゲージにてボルト軸力を計測しながら締め付け後，ヘリウムガスによる内圧（4MPa）およ び曲げモーメント $(2.5,5.0 \mathrm{kN} ・ \mathrm{~m})$ を負荷した。漏えい量の測定は圧力降下法を用いた。本研究では，内圧 負荷と曲げモーメント負荷の負荷順序の違いが密封性能に及ぼす影響を評価した。 また，曲げモーメント作 用時のフランジハブおよびボルトの作用応力を歪みゲージにより測定，評価した.

\footnotetext{
* 原稿受付 2010 年 11 月 8 日

*1 正員, 東京電力(株) 技術開発研究所（２２30-8510 神奈川県横浜市鶴見区江ヶ崎町 4-1）

*2 正員, 広島大学大学院工学研究科

*3 正員, フェロー, 広島大学大学院工学研究科

E-mail: torii.hiro@tepco.co.jp
} 


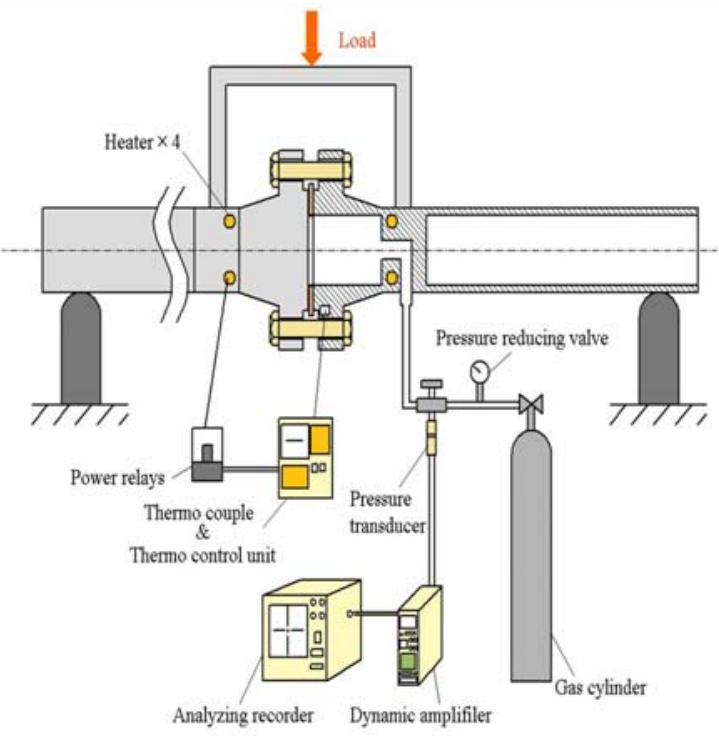

Fig.1 Schematic diagram of experimental setup.

\section{$2 \cdot 2$ 有限要素解析}

曲げモーメント負荷時におけるガスケットの接触応力分布およびフランジ強度について有限要素解析によ り評価した. 4 点曲げ試験における対称性を考慮して，フランジ部から配管途中までの $1 / 2$ モデルに対して応 力解析を行った. ガスケットおよびフランジの要素数は 54680, 節点数は 61966 とした. 解析には汎用有限要

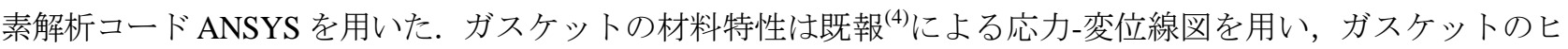
ステリシス，非線型性を考慮した。

\section{3. 結果および考察}

\section{$3 \cdot 1$ 漏えい試験結果}

図 2 は曲げモーメントによる漏えい量の変化を示す. 曲げモーメントの増加に伴い, 漏えい量が増加したこと が確認される，一方，初期目標接触ガスケット応力が高い（100MPa）条件では，漏えい量の増加は見られず，曲 げモーメントの影響を受けにくい結果となっている。このことは，曲げモーメントによらず密封性能を維持する ためには出来るだけ高い接触ガスケット応力で締結することが望ましいことを示唆している. 図 3 は荷重負荷序 が漏えい量に及ぼす影響を示している. 内圧（I.P.）と曲げモーメント（B.M.）の順序の影響について, I.P. $\rightarrow$ B.M. の順序で負荷した方が，漏えい量が小さく密封性能に優れることを示している.

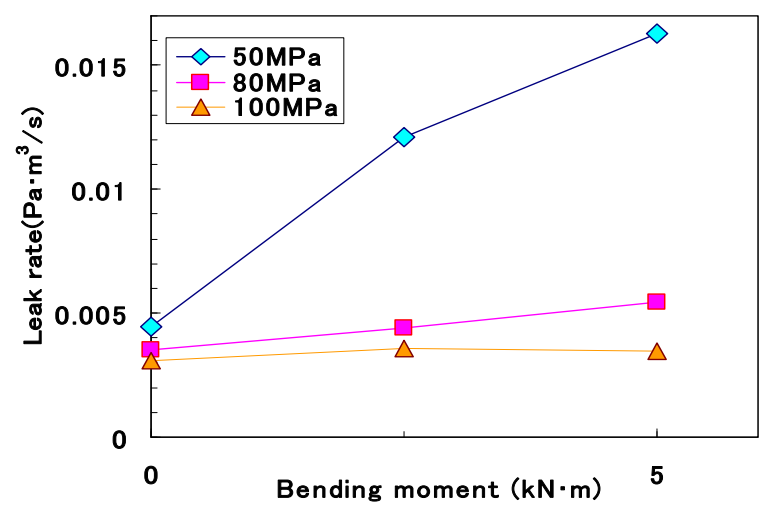

Fig.2 Leak rate obtained experimentally as a function of bending moment. (B.M. $\rightarrow$ I.P.)

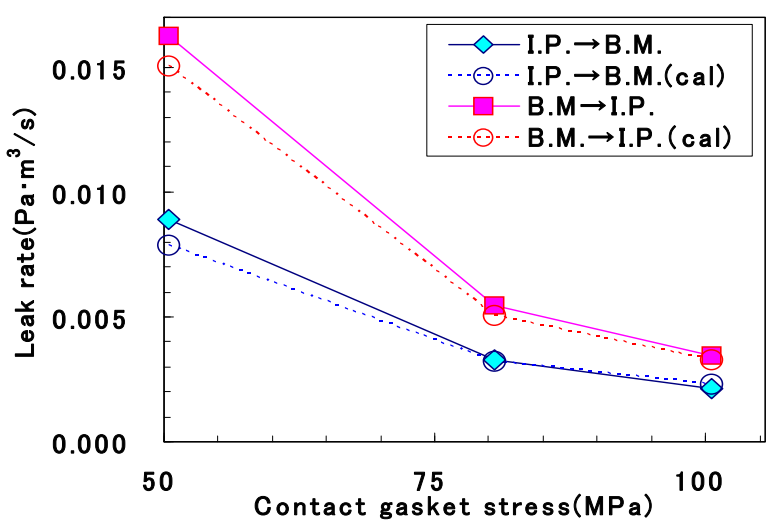

Fig.3 Leak rate obtained experimentally and analytically as a function of contact gasket stress.

(Bending moment $5 \mathrm{kN} \cdot \mathrm{m}$ ) 


\section{$3 \cdot 2$ 有限要素解析結果}

図 4 および図 5 は有限要素解析による接触ガスケット忘力の円周方向分布を示す．内圧の作用により円周方向 に一様な接触ガスケット応力の低下が確認され，曲げモーメントの作用により円周方向に非対称な応力分布が発 生している．この接触ガスケット応力分布の非対称性はガスケットの応力一変位線図の非対称性と対応するもの である．荷重負荷順序の違いによる接触ガスケッ卜応力分布を比較した場合，引張側（図 4，5 における $180^{\circ}$ ）

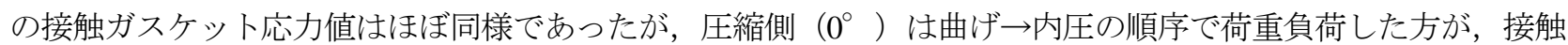
ガスケット応力が低い結果となった。これはガスケットの応力負荷時と除荷時の縦弾性係数が異なるために荷重 負荷の順番の影響を受けて圧縮側の応力が異なる結果となったためと考えられる．接触ガスケットの応力分布か ら漏えい量を既報 (1),(2),(4)に従い、以下の手順にて推定する. ガスケットを等面積に 8 分割して平均接触ガスケット 応力を算出する. JIS による基本漏えい量試験(5)より求めた接触ガスケット応力と漏えい量の関係から, 分割され た試験ガスケットの推定漏えい量を合計することにより試験ガスケット全体の漏えい量を推定する. 図 3 に示す 通り，解析と試験結果はよく一致しており，解析の妥当性が示されている．以上より，曲げモーメント負荷時の 密封性能には，圧縮側の応力分布も影響を受けることが示唆されている.

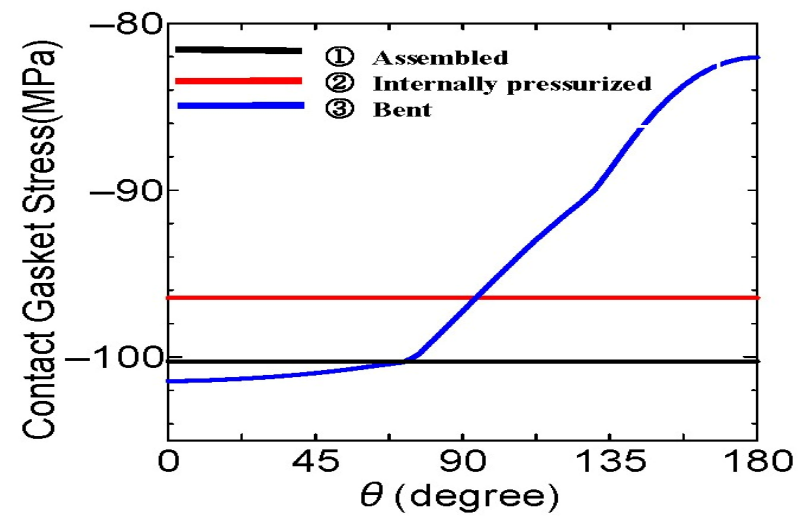

Fig.4 Change in contact gasket stress distribution.

(I.P. $\rightarrow$ B.M.)

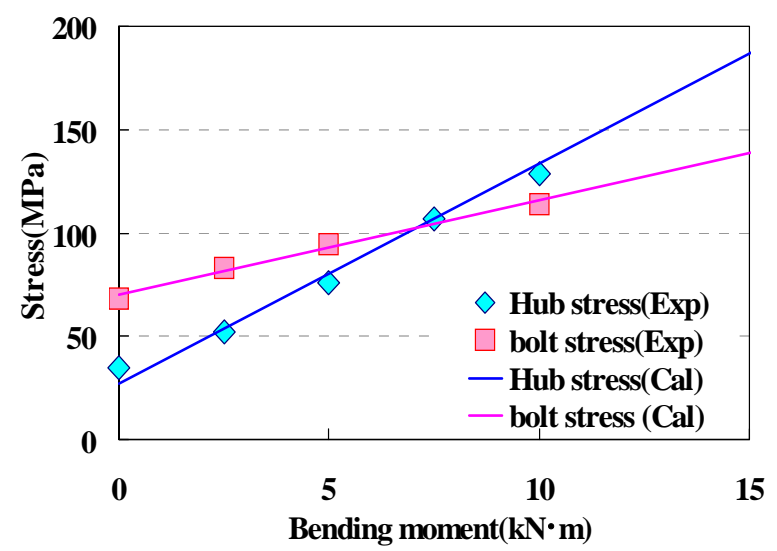

Fig.6 Change in hub stress and bolt stress under bending moment in flange connection.

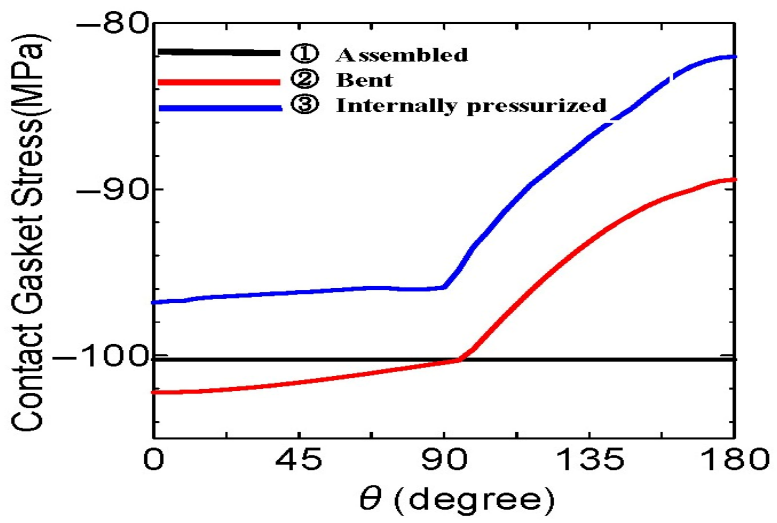

Fig.5 Change in contact gasket stress distribution.

(B.M. $\rightarrow$ I.P.)

フランジ締結体の設計においては密封性の評価と同様に締結体の強度評価も同様に重要である.解析評価より, 曲げモーメントの作用下，フランジハブ部とフランジリングの接合部近傍にて最も作用応力が高いことが示され ている. 図 6 は当該フランジハブ部とボルトについて曲げモーメント作用下における作用応力の試験結果ならび に解析結果を示す．解析結果と実験結果はかなりよく一致していた．フランジ締結状態ではボルト軸部に最も応 力が作用するが, 曲げモーメントの増加に伴いフランジハブ部の作用応力の増加が大きく, 本試験ではフランジ

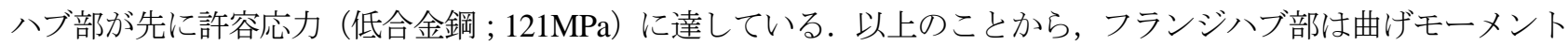
の影響を受けやすく，フランジ強度設計上重要な要素になると考えられる. 


\section{4. 結言}

（1）曲げモーメントの作用により接触ガスケット応力が引張・圧縮側に分布し，密封性能を低下させたが，初期 目標接触ガスケット応力が高い場合には，曲げモーメントによる密封性能低下は小さかった.

（2）荷重負荷（内圧，曲げモーメント）順序の影響については内圧 $\rightarrow$ 曲げモーメントの順序で負荷した方が，漏 えい量が小さく密封性能に優れる結果となった。これはガスケット変形特性の非線形性と関連づけられる.

（3）曲げモーメントの増加に伴い, 八ブ部応力やボルト軸力は直線的に増加した. 特にハブ応力の増加が顕著で あり, 設計上重要な要素になると考えられる。

\section{文献}

(1) 鳥居広康, 高木愛夫,大宮祐也,船田健介, 沢 俊行, “曲げモーメントを受ける管フランジ締結体の密封性能評価”,山梨 講演会論文集, (2009), pp. 178-179.

(2) Y.Takagi, H.Torii, T.Sawa, K.Funada, "Sealing performance evaluation of pipe flange connection with spiral wound gasket under cyclic thermal condition”, ASME PVP2009-77494,(2010)

(3) W.J.Koves, “Analysis of flange joints under external loads”, ASME J. Pressure. Vessel. Technology, 118 (1996),pp.59-63.

(4) Y.Takagi, H.Torii, T.Sawa, Y.Omiya, "Effect of external bending moment on the sealing performance of pipe flange connection”, ASME PVP2010-25180,(2010)

(5) JIS B 2490 “管フランジ用ガスケットの密封特性試験方法” 